\title{
T Lymphocyte lines from arthritic synovial fluid: establishment and function
}

\author{
C J BISHOP, ${ }^{1}$ R A HAZELTON, ${ }^{2}$ D J MOSS, ${ }^{1}$ AND J M RYAN
}

From the ${ }^{1}$ Queensland Institute of Medical Research, Herston, Queensland; and the ${ }^{2}$ University of $\cong$ Queensland Dept of Medicine, Princess Alexandra Hospital, Woolloongabba, Queensland, Australia

SUMmaRY T Lymphocyte lines have been established, with the addition of interleukin-2 (IL-2), from the synovial fluid (SF) of patients with arthritis. Characterisation of seven of these SF-derived $\mathrm{T}$ cell lines showed them to be $\mathrm{T}^{+}, \mathrm{T}_{1} 1^{+}$, and to contain a significant proportion of $\mathrm{c}$ $\mathrm{T}^{+}$cells (mean $41 \%$ ). The proportion of $\mathrm{T}^{+}$cells varied among the lines, with a mean $\mathrm{T} 4^{+} \stackrel{\sim}{\sim}$ $/ \mathrm{T}^{+}$ratio of $0 \cdot 6$. A significant autologous mixed lymphocyte reaction (AMLR) was observed $\vec{\sim}$ only in one of four T cell lines assayed. Two of four lines assayed showed natural killer (NK) cell- 의 like activity, while one line displayed a significant suppressor activity, suggesting that the $\mathrm{T}$ cell $\overrightarrow{-}$ population in SF contained NK-like cells or suppressor cells, or both, either of which may be $\frac{T}{\mathbb{D}}$ selected in the establishment of SF-derived $\mathrm{T}$ cell lines.

Key words: $\mathrm{T}$ lymphocytes, arthritis, $\mathrm{T}$ cell lines.

Some arthritic diseases, such as rheumatoid arthritis (RA), are characterised by the infiltration of large numbers of lymphocytes, especially $T$ cells, into synovial tissue. ${ }^{1}$ The origin and function of these $\mathrm{T}$ cells is unclear. Assays with monoclonal antibodies to $\mathrm{T}$ cell surface markers indicate that in SF there is an increased proportion of $\mathrm{T}^{+}$cells, generally considered to be the cytotoxic/suppressor phenotype, compared with that found in the peripheral blood (PB) of RA patients. ${ }^{2-4}$ Some functional studies of the $\mathrm{T}$ cells isolated from synovial tissue and/or fluid have shown suppressor activity, ${ }^{56}$ whereas others have shown spontaneous cytotoxic activity, ${ }^{78}$ and another has failed to show either. ${ }^{9}$

The aim of the present study was to establish $T$ cell lines from the SF of patients with certain arthritic diseases that would allow analysis of SF T cell function. Previous studies by us ${ }^{10} 11$ have indicated that $T$ lymphocytes isolated from the peripheral blood of patients with acute infectious mononucleosis died rapidly when cultured in vitro. If significant numbers of $\mathrm{T}$ cells isolated from the $\mathrm{SF}$ of arthritis patients also died rapidly in vitro, meaningful assays of SF $T$ cell function would be

Accepted for publication 23 July 1985 .

Correspondence to Dr C J Bishop, Queensland Institute of Medical Research, Bramston Terrace, Herston, Queensland 4006, Australia. difficult to carry out, since $\mathrm{T}$ cell functions hate generally been defined by in vitro assays conducted over periods ranging from 15 hours to seven days, by which time many (if not all) of the T cells may have $\stackrel{\mathbb{Q}}{\mathbb{Q}}$ died.

In the present study we describe the death in vitro $\bar{\partial}$ of $\mathrm{T}$ cells isolated from the SF of patients with three different clinical types of arthritis, show the effect of IL-2 on their survival, report on the establishment of $T$ cell lines from the SF of such patients, and describe functional assays of some of these lines.

\section{Materials and methods}

CULTURE MEDIA

Cells were cultured in RPMI 1640 (Commonwealth Serum Laboratories, Vic.) supplemented with $10 \%$ 을 heat-inactivated human serum, penicillin (100 IU/ $\mathrm{ml})$, and streptomycin $(100 \mu \mathrm{g} / \mathrm{ml})$. Where indicatedo this basic medium was modified by the addition of $20 \%$ crude IL-2 (supernatant from MLA 144 T cellN cultures, kindly provided by Dr A Hapel, John Curtin School of Medical Research, Canberra).

LYMPHOCYTE DONORS

Mononuclear cells were isolated from the SF or PB of five patients with classical or definite RA (American Rheumatism Association criteria), one patient $\stackrel{\mathbb{D}}{\mathscr{D}}$ 
with reactive arthritis (React A) due to Yersinia enterocolitica, and one with psoriatic arthritis (PsA), and from the PB of four healthy controls. Most patients were receiving non-steroidal antiinflammatory drugs. Patients receiving steroid treatment were excluded.

LYMPHOCYTE SEPARATION

Unfractionated mononuclear (UM) cells were isolated from the SF or heparinised PB by isopyknic centrifugation on Ficoll-Paque (Pharmacia) as described previously. ${ }^{12}$ UM cells were mixed with 2aminoethylisothiouronium bromide treated sheep erythrocytes and the $E$ rosetting $(T)$ cell population isolated essentially as previously described. ${ }^{13}$ In some cases the SF was added, immediately on collection, to an equal volume of culture medium containing $40 \%$ IL-2, and all solutions used in the subsequent lymphocyte separation contained $20 \%$ IL-2.

\section{MARKERS OF CELL DEATH}

Certain histological changes associated with cell death, classically designated as nuclear pyknosis and karyorrhexis, occur in both necrosis and apoptosis. ${ }^{14}$ is Necrotic cells also show karyolysis and swelling of the cytoplasm, which eventually loses its basophilia, and cell boundaries become indistinct. ${ }^{14-16}$ Apoptotic cells appear to be condensed, typically with intensely eosinophilic cytoplasm, which frequently shows surface protrusion. These protuberances separate to form roughly spherical bodies sometimes containing basophilic nuclear fragments. ${ }^{14} 15$

One commonly employed marker of cell death, dye exclusion, is a poor indicator of cell death by apoptosis. Apoptotic cells exclude dye until they undergo secondary disintegration. ${ }^{17}$

\section{Apoptosis}

Smears were air dried, fixed with methanol, and stained with haematoxylin and eosin. The percentage of cell death by apoptosis was estimated from counts of 500 cells in each smear by an oil immersion objective. Where it was impossible to delineate apoptotic bodies in a compact cluster, the cluster was scored as one: the counts were thus only approximate.

\section{Dye-excluding cells}

A $20 \mu \mathrm{l}$ cell suspension was diluted with $20 \mu \mathrm{l} 0.5 \%$ aqueous trypan blue and the stained and nonstained cells were counted in a haemocytometer.

STUDIES ON THE RESPONSE TO IL- 2

$\mathrm{T}$ Cells from the SF of patients were isolated either in the presence or absence of $20 \%$ IL-2 and subsequently maintained in culture media supplemented with $20 \%$ IL- 2 or in unsupplemented media respectively. Twenty-four hours after seeding the percentage of dye-excluding cells and of apoptotic cells was determined in each culture.

\section{ESTABLISHMENT OF SF-DERIVED T CELL} LINES

$\mathrm{T}$ Cells were isolated from the SF of patients in the presence of $20 \%$ IL-2 and seeded into Linbro tissue culture plates $(2 \mathrm{ml} / \mathrm{well})$ at $2.5 \times 10^{5} \mathrm{cells} / \mathrm{ml}$ in culture medium supplemented with $20 \%$ IL-2. Cultures were incubated at $37^{\circ} \mathrm{C}$ in a humidified atmosphere of $5 \% \mathrm{CO}_{2}$ in air. Culture medium was replaced approximately every four days until proliferation was evident, at which time the cultures were split 1:2 with new culture medium supplemented with $20 \%$ IL-2 and with $10^{4}$ irradiated (8000 cGy) autologous Epstein-Barr virus (EBV)-transformed lymphoblastoid cell lines (LCLs)/ml. ${ }^{18}$ Subsequent splits were made approximately every four days with culture media supplemented with $20 \%$ IL-2 and irradiated autologous LCLs.

\section{CHARACTERISATION OF CELL SURFACE M A R K E R S}

Cell markers were assayed by means of monoclonal antibodies (MoAb) (Ortho-mune, Ortho Diagnostic Systems, Raritan, NJ) and fluorescein-labelled goat antimouse IgG antibody (Kirkegaard and Perry Laboratories, Gaithersburgh, MD) in conjunction with a Becton-Dickinson FACS IV cell sorter, according to the manufacturer's instructions (Orthomune). The assays were carried out on some freshly isolated SF T cells, on the established SF-derived T cell lines after they had been established for greater than four weeks, and on a number of previously characterised cell lines with known markers. ${ }^{19}$

\section{AUTOLOGOUS MIXED LYMPHOCYTE} REACTION

The autologous mixed lymphocyte reaction (AMLR) was carried out in 96-well round-bottomed microtitre plates (Disposable Products, Brisbane, Australia) in a chequerboard design with 1.0 $1.5 \times 10^{5}$ responder cells and an equal number of mitomycin $C$ treated $(40 \mu \mathrm{g} / \mathrm{ml}$ cells for 20 minutes at $37^{\circ} \mathrm{C}$ ) stimulator cells in a final volume of $200 \mu \mathrm{l}$ per well. All cultures were incubated at $37^{\circ} \mathrm{C}$ in $5 \%$ $\mathrm{CO}_{2}$ in air for six days. $1 \mu \mathrm{Ci} /$ well of $\left[{ }^{3} \mathrm{H}\right]$ thymidine (New England Nuclear, Boston, Mass) was added 18-20 hours before harvest. The cells were harvested with a multisample harvester (Skatron) and the incorporation of $\left[{ }^{3} \mathrm{H}\right]$ thymidine determined by standard liquid scintillation counting techniques. 
Results were analysed as mean counts per minute (cpm) in quadruplicate cultures minus the background $\mathrm{cpm}$ in responder cells when incubated alone. An AMLR was carried out on the SF-derived $T$ cell lines after they had been established for at least four weeks. T Cells from the SF-derived lines, PB UM cells, and allogeneic LCLs from two healthy donors were used alternatively as responders or stimulators in the assays. Phytohaemagglutinin (PHA-P, Difco, Michigan) responsiveness was also assayed.

CHROMIUM RELEASE ASSAY FOR T CELL CYTOTOXICITY

The assay was carried out as previously described. ${ }^{20}$ Briefly, $100 \mu \mathrm{l}$ effector cells $\left(10^{6}\right.$ cells $\left./ \mathrm{ml}\right)$ were added to $100 \mu$ l chromium-51 labelled target cells $\left(10^{5}\right.$ cells $\left./ \mathrm{ml}\right)$ in microtest plates, the plates were lightly centrifuged $\left(200 \mathrm{~g}, 5 \mathrm{~min}, 37^{\circ} \mathrm{C}\right)$, and incubated for five hours at $37^{\circ} \mathrm{C}$. After centrifugation $100 \mu \mathrm{l}$ of supernatant was harvested and counted for radioactivity. Assays were carried out in triplicate and the percentage specific cell lysis calculated from mean values by:

$$
\frac{\text { test release }- \text { spontaneous release }}{\text { maximum release }- \text { spontaneous release }} \times 100
$$

where test release was that obtained from target cells incubated with effector cells, spontaneous release was that from target cells incubated alone, and maximum release was that from target cells incubated in the presence of $1 \%$ sodium dodecyl sulphate. Target cells were autologous LCLs, allogeneic LCLs from other arthritis patients, and the natural killer cell (NK) sensitive K562 cell line. ${ }^{21}$

ASSAY FOR T CELL SUPPRESSOR ACTIVITY Cells from the SF-derived $T$ cell lines from patient 5 or patient 7 were incubated at various concentra- tions with autologous PB UM responder cells $\left(5 \times 10^{4}\right.$ cells/well) and mitomycin $\mathrm{C}$ treated $(40 \mathrm{~N}$. $\mu \mathrm{g} / \mathrm{ml}$ cells for $20 \mathrm{~min}$ at $37^{\circ} \mathrm{C}$ ) stimulator cells? $\left(5 \times 10^{3}\right.$ cells/well or $1.6 \times 10^{3}$ cells/well $)$ in 96 -wele flat-bottomed microtitre plates in a final volume ofo $200 \mu \mathrm{l} /$ well. The cells used as stimulators consistedo of equal numbers of allogeneic LCLs from two healthy donors. All cultures were incubated at $37^{\circ} \mathrm{CD}$ in $5 \% \mathrm{CO}_{2}$ in air for five or seven days. $1 \mu \mathrm{Ci} /$ well of $\left[{ }^{3} \mathrm{H}\right]$ thymidine was added eight hours before har ${ }^{\infty}-$ vest. The cells were harvested with a multisample $\overrightarrow{0}$ harvester and counted. Results are expressed as mean cpm in quadruplicate wells minus the back- $-\omega$ ground cpm in the autologous PB UM responder cells incubated alone.

\section{Results}

DEATH OF SF CELLS IN VITRO AND RESPONSEO TO IL-2

Smears prepared from cultures of SF $T$ cells incubated in the absence of IL-2 showed that theseO cultures contained an increasing number of condensed cells with intensely eosinophilic cytoplasms, basophilic nuclear fragments, and surface protuber $-\overrightarrow{0}$ ances. These are histological markers associatôdo with cell death by apoptosis, which remained at low level in cultures containing $20 \%$ IL-2. The meano percentage $( \pm S D)$ of cell death by apoptosis in individual cultures of SF T cells $24 \mathrm{~h}$ after isolation from four patients and incubated in the absence of IL-2 was $10 \cdot 0 \pm 1 \cdot 3$, while it was significantly lower, $3 \cdot 1 \pm 1 \cdot 6$, in cultures containing $20 \%$ IL-2 $(\mathrm{p}<0 \cdot 01)$.

CELL SURFACE CHARACTERISATION OF ESTABLISHED SF T CELL LINES

Table 1 shows the percentage of $T$ cells from established SF-derived $T$ cell lines and of some freshly isolated SF T cells reacting with MoAb. The

Table 1 Cell surface characterisation of established SF-derived $T$ cell lines and freshly isolated $S F T$ cells

\begin{tabular}{|c|c|c|c|c|c|c|}
\hline \multirow[t]{2}{*}{ Patient (diagnosis) } & \multicolumn{6}{|c|}{ Cells reacting with $M o A b(\%)$} \\
\hline & $\mathrm{T3}^{+}$ & $\mathrm{T4}^{+}$ & $T 8^{+}$ & $\mathrm{T}^{+} \mathrm{I}^{+}$ & Leu $11 a^{+}$ & $T 4^{+} / T 8^{+}$ \\
\hline \multicolumn{7}{|l|}{$S F$-derived $T$ cell lines } \\
\hline 1 (React A) & $43 \cdot 0$ & $34 \cdot 1$ & $39 \cdot 4$ & $93 \cdot 9$ & - & $0 \cdot 9$ \\
\hline 2 (RA) & $73 \cdot 3$ & $27 \cdot 4$ & $24 \cdot 0$ & $92 \cdot 5$ & - & $1 \cdot 1$ \\
\hline 3 (RA) & $47 \cdot 5$ & $10 \cdot 8$ & $48 \cdot 7$ & - & $23 \cdot 2$ & $0 \cdot 2$ \\
\hline 4 (RA) & $74 \cdot 9$ & $27 \cdot 0$ & $52 \cdot 7$ & $87 \cdot 0$ & $23 \cdot 2$ & $0 \cdot 5$ \\
\hline 5 (PsA) & $68 \cdot 4$ & $35 \cdot 7$ & $31 \cdot 7$ & $83 \cdot 8$ & $17 \cdot 2$ & $1 \cdot 1$ \\
\hline 6 (RA) & $78 \cdot 4$ & $20 \cdot 0$ & $42 \cdot 2$ & - & $4 \cdot 3$ & $0 \cdot 5$ \\
\hline 7 (RA) & $63 \cdot 4$ & $4 \cdot 5$ & $44 \cdot 9$ & $85 \cdot 6$ & $19 \cdot 4$ & $0 \cdot 1$ \\
\hline \multicolumn{7}{|l|}{ Freshly isolated $S F$ cells } \\
\hline 2 (RA) & $87 \cdot 5$ & $38 \cdot 1$ & $17 \cdot 9$ & - & - & $2 \cdot 1$ \\
\hline 3 (RA) & $85 \cdot 5$ & $53 \cdot 0$ & $24 \cdot 4$ & 一 & - & $2 \cdot 2$ \\
\hline
\end{tabular}


percentage of cells from the established lines that were $\mathrm{T}^{+}$and $\mathrm{T} 11^{+}$was generally high. The mean percentage of cells that were $\mathrm{T}^{+}$, indicative of the cytotoxic/suppressor population, was $41 \%$, while the mean percentage of cells that were $\mathrm{T}^{+}$, indicative of the helper population, was $23 \%$. In three lines the $\mathrm{T}^{+} / \mathrm{T}^{+}$ratio was approximately 1 , while in the other lines the $\mathrm{T} 8^{+}$cells predominated over $\mathrm{T}^{+}$cells. The mean $\mathrm{T}^{+} / \mathrm{T}^{+}$ratio was approximately $0 \cdot 6$. Some lines were Leu $11 \mathrm{a}^{+}$, a marker indicative of NK cell phenotype, though the proportion was $\leqslant 25 \%$. In contrast, the mean $\mathrm{T} 4^{+} / \mathrm{T}^{+}$ratio of two populations of freshly isolated SF T cells was $2 \cdot 15$.

FUNCTIONAL STUDIES OF ESTABLISHED SFT CELL LINES

Only one of four established SF derived T cell lines assayed showed a significant stimulation in AMLR. Mitomycin treated T cells from the line derived from the SF of patient 5 (PsA) stimulated an AMLR of $5062 \pm 218$ (mean \pm SD of quadruplicate cultures) with autologous PB UM cells. Mitomycin C treated $T$ cells from the SF-derived lines from patients 1 (React A), 4 (RA), and 7 (RA) did not stimulate a significant AMLR with autologous PB UM cells. Mitomycin C treated autologous PB UM cells did not stimulate a significant AMLR when T cells from any of the SF-derived lines were used as responders. Cells from the SF-derived $T$ cell lines did not respond significantly to PHA-P.

Table 2 shows that, where tested, established SFderived $\mathrm{T}$ cell lines displayed insignificant or weak cytotoxicity to autologous and allogeneic LCLs (not HLA related) but in some cases were strongly cytotoxic to the NK-sensitive K562 cell line.

One of the established SF-derived $\mathrm{T}$ cell lines showed high levels of suppressor activity (Fig. 1 shows patient 5), whereas another showed little or no suppression (patient 7 , not shown).

\section{Discussion}

The death in vitro of $T$ lymphocytes isolated from the synovial fluid of arthritis patients was significantly reduced by the addition of IL-2 $(p<0 \cdot 01)$ and

Table 2 Cytotoxicity of established SF-derived T cell lines

\begin{tabular}{|c|c|c|c|}
\hline \multirow{2}{*}{$\begin{array}{l}\text { Patient } \\
\text { (diagnosis) }\end{array}$} & \multicolumn{3}{|l|}{ Specific lysis (\%) } \\
\hline & Autologous LCLs & Allogeneic LCLs & K562 \\
\hline 4 (RA) & - & $3 \cdot 5$ & $7 \cdot 8$ \\
\hline 5 (PsA) & - & 2.7 & $19 \cdot 2$ \\
\hline 6 (RA) & $6 \cdot 8$ & $15 \cdot 5$ & 61.5 \\
\hline 7 (RA) & $2 \cdot 9$ & $\leqslant 1$ & 61.0 \\
\hline
\end{tabular}

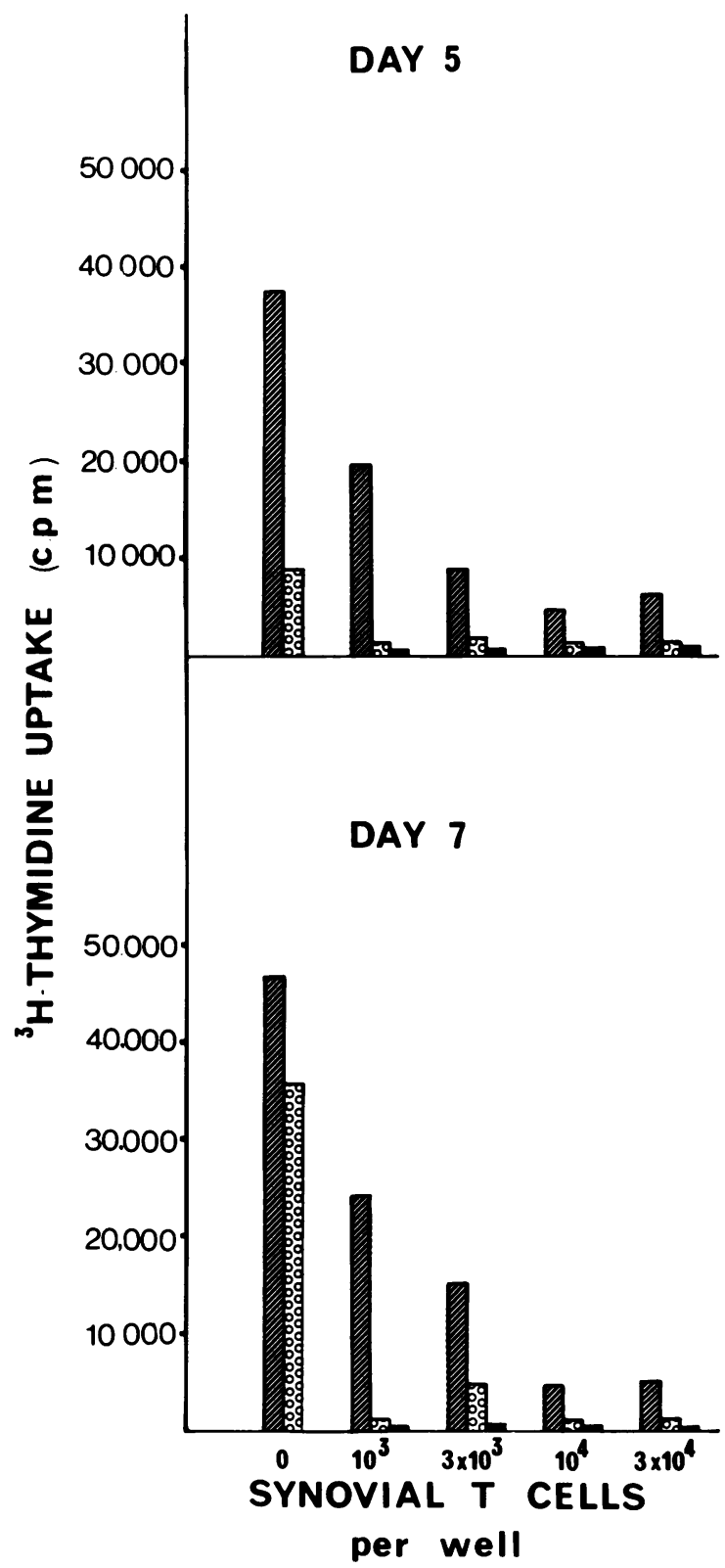

Fig. $1\left[{ }^{3} \mathrm{H}\right]$ Thymidine uptake (cpm) by autologous $P B$ $U M$ responder cells $\left(5 \times 10^{4}\right.$ cells/well) incubated for five or seven days with mitomycin $C$ treated stimulated cells at $5 \times 10^{3}$ or $1.6 \times 10^{3}$ cells/well in the presence of increasing concentrations of cells from a SF-derived T cell line (patient 5). $\left[^{3} H\right]$ Thymidine uptake was high if SF T cells were absent but decreased with increasing concentrations of SF T cells. $\left[^{3} \mathrm{H}\right]$ Thymidine uptake was low if stimulator cells were omitted $\mathbf{a}$. 
allowed SF-derived $\mathrm{T}$ cell lines to be readily established. SF T cell lines were established from greater than $75 \%$ of the patients. The use of IL-2 to generate SF $T$ cell lines has also been recently reported, ${ }^{22}$ when such lines were established from approximately $25 \%$ of RA patients.

IL-2 support of the in vitro growth of $\mathrm{T}$ cells isolated from the SF of arthritis patients was not unexpected. SF T cells show characteristics associated with activated T cells, ${ }^{2}{ }^{2.3}$ and IL-2 has been shown to support the growth of activated $T$ lymphocytes. ${ }^{24}$ IL-2 like material has been shown in the synovial fluid of RA patients. ${ }^{25}$ The kinetics of the death of SF T cells in vitro after their isolation and culture in IL-2 free medium were similar to those previously described for infectious mononucleosis derived T cell lines after the removal of IL$2 .^{11}$

As expected, all of the established SF T cell lines that we characterised with $\mathrm{T} \mathrm{MoAb}$ were $\mathrm{T}^{+}$and, where tested, $\mathrm{T}_{11}{ }^{+}$. All lines contained a significant proportion of cells that were $\mathrm{T}^{+}$, while the proportion of $\mathrm{T}^{+}$cells varied among the lines, with the $\mathrm{T}^{+}$population predominating in over half of the lines (four of seven, $\mathrm{T}^{+} / \mathrm{T} 8^{+}$ratio $\leqslant 0 \cdot 5$ ) and equal proportions of $\mathrm{T}^{+}$and $\mathrm{T}^{+}$in the remainder (three of seven, $\mathrm{T}^{+} / \mathrm{T} 8^{+}$ratio approximately 1$)$. $\mathrm{T} 8^{+}$Cells also predominate in other SF T cell lines established recently. ${ }^{22} \mathrm{~A}$ number of studies have shown a higher proportion of $\mathrm{T}^{+} \mathrm{T}$ cells in the synovial fluid of RA patients than in the peripheral blood of either RA patients or normal controls. ${ }^{2-4}$ However, although the proportion of $\mathrm{T}^{+}$cells in the established lines was more often higher than that of the $\mathrm{T}^{+}$cells, the reverse was the case in the two freshly isolated SF T cell populations that subsequently gave rise to $T$ cell lines. This suggests that $\mathrm{T}^{+}$cells may be selected against $\mathrm{T}^{+}$cells during the establishment of these lines, possibly arising from differences in responsiveness to IL-2, indicating that the T cell population in the SF-derived lines did not represent that in the $\mathrm{SF}$ in vivo.

The cells from only one of four established SF T cell lines showed a significant AMLR when they were used as stimulators. There was no significant AMLR when the cells from these lines were used as responders. This is not unexpected, as it has been shown that freshly isolated SF $\mathrm{T}$ cells are poor responders in the $A_{M L R^{26}} 27$ and that the previously observed stimulation of autologous or allogeneic PB lymphocytes by SF UM cells appears to be mediated largely by the non- $T$ cell population. ${ }^{26} 27$ Moreover, a $T$ cell-T cell AMLR has been described in the PB, where the presence of activated $T$ cells was responsible for the generation of $T$ cells bearing the suppressor phenotype. ${ }^{28}$ This may explain why the line derived from the psoriatic $\frac{2}{3}$

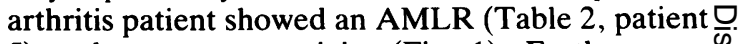
5) and suppressor activity (Fig. 1). Furthermore, these SF-derived lines are presumably polyclonal.

A number of previously reported studies showed a NK cell-like activity associated with SF lymphocyte $\frac{\bar{O}}{0}$ populations. ${ }^{78}$ Some of the established SF T cell $\overline{\frac{\bar{p}}{}}$. lines described contained a population of cells that $\widehat{\nabla}$ were Leu $11 \mathrm{a}^{+}$and were cytotoxic to the $\mathrm{NK}-\frac{2}{0}$ sensitive K562 cell line, suggesting that these lines ${ }^{\infty}$ contained NK-like cells. However, none of the $\vec{\circ}$ established SF T cell lines were significantly cyto- $-\overrightarrow{-}$ toxic to either autologous or allogeneic LCLs.

One of the SF T cell lines displayed significanto suppressor activity, indicating the presence of sup- $\frac{0}{2}$ pressor cells, while another SF T cell line displayedor little suppressor activity. Although MoAb analysis? indicated a significant $\mathrm{T}^{+}$population, generally $\overrightarrow{0}$ considered to be the cytotoxic/suppressor pheno-

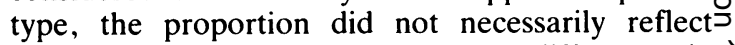
functional activity. This may be due to differences in $\vec{T}$ the proportions of cells that were activated or to theo presence of functionally different subsets bearing particular T cell markers: for example, it has beene shown that $\mathrm{T}^{+}$cells can also have suppressor ${ }^{29}$ or $\rightarrow$ NK-like activities. ${ }^{30}$ (

The studies reported here suggest that the $\mathrm{T}$ cenl! population in the SF of arthritis patients contai NK-like cells or suppressor cells, or both, either:任 which can be selected in the establishment of SF-derived T cell lines. However, they also indicate that the $T$ cell population in these lines does not represent that found in the SF in vivo, and thus the $\overrightarrow{\vec{F}}$ functional activity and antigen reactivity of these cello lines may reflect neither the types of immunereactions occurring in the rheumatoid joint nor theiro relative importance but rather the responsiveness of certain cells to IL-2. It will be necessary to clonea cells early from the SF in order to define the functional profile of the in vivo $\mathrm{T}$ cell population.

We would like to thank Mr G Robert for technical assistance and the National Health and Medical Research Council of Australia for $\stackrel{0}{\square}$ financial support.

\section{References}

1 Abrahamsen T G, Froland S S, Natvig J B, Pahle J. Elution and characterization of lymphocytes from rheumatoid inflammatory tissuc. Scand J Immunol 1975; 4: 823-30.

2 Fox R I, Fong S, Sabharwal N, Carstens S A, Kung P C Vaughan J H. Synovial fluid lymphocytes differ from peripherał blood lymphocytes in patients with rheumatoid arthritis. Immunol 1982; 128: 351-4.

3 Duclos M, Zeidler H, Liman W, Pichler W J, Ricber P. Peter $\mathrm{H} \mathrm{H}$. Characterization of blood and synovial fluid lymphocytes from patients with rheumatoid arthritis and other joint diseases by monoclonal antibodies (OKT series) and acid $\alpha$-naphthy esterase staining. Rheumatol Int 1982; 2: 75-82. 
4 de Vries E. Meyer C J L M. Lafeber G J M. Cnossen J. Cats A. Lymphocyte subpopulations in rheumatoid arthritis. An immunological, enzyme histochemical and morphological study. Rheumatol Int 1984; 4: 91-4.

5 Egeland T. Lea T. Mellbyte O J. T-cell immunoregulatory functions in rheumatoid arthritis patients. Scand J Immunol 1983; 18: $355-62$.

6 Ranki A. Paavonen T. Tolvanen E. Kankaanpaa U. Hayry P. T lymphocyte subclasses in rheumatoid synovia as analysed with monoclonal antibodies and functional in vitro tests. Scand $J$ Immunol 1984: 13: 67-76.

7 Reinitz E. Neighbour P A, Grayzel A I. Natural killer cell activity of mononuclear cells from rheumatoid patients measured by a conjugate-binding cytotoxicity assay. Arthritis Rheum 1982; 12: 1440-4.

8 Silver R M, Redelman D. Zvaifler N J, Naides S. Studies of rheumatoid synovial fluid lymphocytes. I. Evidence for the activated natural killer - (NK) like cells. J Immunol 1982; 128: 1758-63.

9 Romain P L. Burmester G R. Enlow R W, Winchester R J. Multiple abnormalities in immunoregulatory function of synovial compartment $T$ cells in patients with rheumatoid arthritis. Recognition of a helper augmentation effect. Rheumatol Int 1982: 2: 121-7.

10 Moss D J. Bishop C J. Burrows S R, Ryan J M. T lymphocytes in infectious mononucleosis. I. T cell death in vitro. Clin Exp Immunol 1985; 60: 61-9.

11 Bishop C J, Moss D J, Ryan J M, Burrows S R. T lymphocytes in infectious mononucleosis. II. Response in vitro to interleukin-2 and establishment of $\mathrm{T}$ cell lines. Clin Exp Immunol 1985; 60: 70-7.

12 Boyum A. Isolation of mononuclear cells and granulocytes from human blood. Scand J Clin Lab Invest 1968; 21 (suppl 97): 77-89.

13 Kaplan M E. Clark C. An improved rosetting assay for detection of human T lymphocytes. J Immunol Methods 1974; 5: $131-5$.

14 Wyllic A H. Kerr J F R, Currie A R. Cell death: the significance of apoptosis. Int Rev Cytol 1980; 68: 251-306.

15 Searle J. Kerr J F R. Bishop C J. Necrosis and apoptosis: distinct modes of cell death with functionally different significance. Pathol Annu 1982; 17: 229-59.

16 Trump B F. Arstila A U. Cellular reaction to injury. In: Lavia M F, Hill R B. eds. Principles of pathobiology. 2nd ed. New York: Oxford University Press, 1975: 9-96.

17 Sheridan J W. Bishop C J. Simmons R J. Biophysical and morphological correlates of kinetic change and death of a starved human melanoma line. J Cell Sci 1981; 49: 119-37.

18 Moss D J, Pope J H. Assay of the infectivity of Epstein-Barr virus by transformation of human leukocytes in vitro. J Gen Virol 1972; 17: 233-6.

19 Misko I S, Pope J H, Hutter R, Sozynski T D, Kane R G. HLA-DR-antigen-associated restriction of EBV-specific cytotoxic T-cell colonies. Int J Cancer 1984; 33: 239-43.

20 Moss D J, Wallace L E. Rickinson A B, Epstein M A. Cytotoxic T-cell recognition of Epstein-Barr-virus-infected B cells. I. Specificity and HLA restriction of effector cells reactivated in vitro. Eur $J$ Immunol 1981; 11: 686-93.

21 Lozzio C B, Lozzio B B. Human chronic myclogenous leukaemia cell line with positive Philadelphia chromosome. Blood 1975; 45: 321-34.

22 Wilkins $\mathbf{J}$ A, Olivier S, Warrington $\mathbf{R} \mathbf{J}$. Generation of interleukin-2-dependent $T$ cell lines from synovial fluids in rheumatoid arthritis. Clin Exp Immunol 1984; 58: 1-6.

23 Galili U, Rosenthal L, Klein E. Activated T cells in the synovial fluid of arthritic patients. J Immunol 1981; 127: 430-2.

24 Smith K A. T cell growth factor. Immunol Rev 1980; 51 : 338-57.

25 Wilkins J A. Warrington R J, Sigurdson S L. Rutherford W J. The demonstration of an interleukin 2-like activity in the synovial fluids of rheumatoid arthritis patients. J Rheumatol 1983; 10: 109-13.

26 Silver R M. Redelman D, Zvaifler N J. Studies of rheumatoid synovial fluid lymphocytes. II. A comparison of their behaviour with blood mononuclear cells in the autologous mixed lymphocyte reaction and response to TCGF. Clin Immunol Immunopathol 1983; 27: 15-27.

27 Cross S M, Hazelton R A. Correlation of disease activity and drug therapy with the autologous mixed lymphocyte reaction in rheumatoid arthritis. Ann Rheum Dis 1985; 44: 224-31.

28 Damle N K. Gupta S. Autologous mixed lymphocyte reaction in man. V. Functionally and phenotypically distinct human Tcell subpopulations respond to non-T and activated T-cells in AMLR. Scand J Immunol 1982; 16: 59-68.

29 Thomas Y, Rogozinski L. Irigoyen $\mathrm{H}$ et al. Functional analysis of human T-cell subsets defined by monoclonal antibodies. IV. Induction of suppressor cells within the $\mathrm{OKT}^{+}$population. $J$ Exp Med 1981; 154: 459-67.

30 Rimm I. Schlossman S, Reinherz E. Antibody dependent cellular cytotoxicity and natural killer-like activity are mediated by subsets of activated T-cells. Clin Immunol Immunopathol 1981; 21: 134-40. 